http://dx.doi.org/10.30681/23588403v11i01226230

\title{
O ENSINO DE VOCABULÁRIO EM UM LIVRO DIDÁTICO DE LÍNGUA ALEMÃ
}

Data de recebimento: $14 / 03 / 2018$

Aceite: 30/04/2018

Natália Navrotzki RIEDNER (UFRGS) ${ }^{1}$

FINSTER, A. et al. Panorama: Deutsch als Fremdsprache. Berlin: Cornelsen Schulverlage GmbH, 2015.

A coleção de livros de língua alemã "Panorama: Deutsch als Fremdsprache" foi lançada em 2015 pela editora Cornelsen e é composta pelo Kursbuch (livro de curso ${ }^{2}$ ) e pelo Arbeitsbuch (livro de exercícios), dos níveis A1 ao B1³ . Essa coleção foi a escolhida para ser objeto de análise aqui resenhado por ser bastante atual, o que nos permite averiguar de que forma o ensino de vocabulário de língua alemã está sendo abordado pelos livros didáticos recentes. De acordo com a editora Cornelsen, Panorama, assim como o próprio nome já diz, oferece ao aluno uma visão ampla da língua alemã e dos ambientes de vida dos países falantes dessa língua. O conceito de aprendizagem presente nessa coleção envolve exercícios de interação variados com ações que promovem a linguagem ativa. Também há a possibilidade de se utilizar alguns recursos midiáticos, como vídeos que podem ser acessados pelos estudantes através do aplicativo ou de DVDs. Ainda sobre isso, a editora afirma que através do aplicativo pode-se aprofundar individualmente a aprendizagem de vocabulário, gramática e fonética.

O Kursbuch A1.1, primeiro livro da coleção e também objeto de análise desta resenha, é dividido em oito pequenos capítulos. Ao final de cada capítulo há uma seção intitulada Alles klar!, na qual é feita uma rápida revisão sobre o conteúdo estudado naquela parte. A fim de não tornar este trabalho muito extenso, decidiu-se que a análise do ensino de vocabulário do Kursbuch A1.1 abordará os capítulos um, quatro e oito por serem, respectivamente, início, meio e fim do livro. Portanto, primeiramente será feita uma rápida exposição dos capítulos citados acima para, então, serem analisados conjuntamente.

\footnotetext{
${ }^{1}$ Mestranda no Programa de Pós-Graduação em Linguística Aplicada da Universidade Federal do Rio Grande do Sul (Porto Alegre/Brasil). Email: natalia.riedner@ gmail.com.br

2 Tradução livre.

${ }^{3}$ Níveis correspondentes ao Quadro Comum Europeu de Referência para Línguas (CEFR).
} 
O índice oferece um compilado dos assuntos de cada capítulo envolvendo os seguintes itens: usos da língua, temáticas e textos; campo de palavras; gramática. Segue abaixo a tabela com as informações dos campos de palavras presentes no índice dos três capítulos que serão abordados nesta resenha:

\begin{tabular}{|c|l|}
\hline 1 & Formas de cumprimentar e se despedir; coisas que gostamos ou não; \\
\hline 4 & Coisas que (não) gostamos de comprar; \\
\hline 8 & Horários; momentos do dia; meses do ano. \\
\hline
\end{tabular}

O capítulo um, intitulado Willkommen!, inicia com pequenos e simples diálogos, introduzindo o conteúdo sobre tipos de cumprimentos e despedidas, tanto formais quanto informais, os quais os estudantes devem ouvir e identificar a figura correspondente. Os exercícios seguintes são de completar as expressões, como Guten , exigindo que o aluno complete Guten Tag, por exemplo. Ao final da página, há um pequeno espaço destinado a essas formas de expressões na Áustria e na Suíça. Tais expressões ditas na Alemanha são retomadas em diálogos mais complexos, envolvendo perguntas como "de onde você vem" e “onde você mora", com a possibilidade de assistir essas conversas pelo DVD.

O próximo campo de palavras do capítulo um, que são as coisas que gostamos ou não, aparecem em um bate-papo virtual entre pessoas desconhecidas, para que o estudante leia e preencha uma tabela com as informações Wer?, Wo?, Woher? e Was? (respectivamente Quem?, Onde?, De onde?, O quê?). Depois, o livro apresenta uma lista complementar de coisas contendo a imagem e a palavra no singular - como a imagem de um cinema e a palavra Kino (cinema) -, e propõe que a turma responda a pergunta "Quem gosta de...?", usando as coisas da lista. Na seção Alles klar! do capítulo um, apenas uma parte do vocabulário é retomado, sempre incorporado à frases. Por exemplo:

Was magst du?

Do que você gosta?
Ich mag Sport, Kino und Musik.

Eu gosto de esporte, cinema e música.

Na metade do livro, o capítulo quatro Und heute: Shoppen!, também inicia com a apresentação do novo vocabulário, porém de uma forma diferente da do primeiro capítulo. 
Und heute: Shoppen! começa com quatro imagens - duas de pessoas em lojas e duas de pessoas conversando sobre suas compras - onde aparecem diversos objetos, por exemplo: a) vestido; b) jaqueta; c) bolsa. Logo abaixo há uma lista de palavras desses objetos na língua alemã, em que os alunos devem identificar a palavra à letra correspondente na figura e, além disso, escrever a sua forma plural. Alguns desses objetos foram apresentados no capítulo anterior e outros são novos, aparecendo também em uma lista com: imagem, palavra no singular e no plural. O vocabulário é reforçado no próximo exercício, uma entrevista em que um colega deve perguntar ao outro se ele gosta de ir às compras e o que ele (não) gosta de comprar - há exemplos de possíveis respostas, a fim de ajudar os alunos.

Ao final do capítulo há a imagem de um blog, onde uma mulher conta aos seus leitores os lugares que ela visitou na cidade de Hamburgo (Alemanha). Nesse texto são retomados alguns adjetivos vistos no capítulo três, mas também são inseridos alguns novos, como toll e sehr gut (legal e muito bom), por exemplo, seguidos de um exercício de diálogo em que é dado um exemplo de pergunta e de resposta, para que o aluno siga treinando os adjetivos. No último exercício do capítulo é proposto ao aluno que ele escreva um Blogtext (texto de blog) sobre a sua cidade, usando os mesmos adjetivos. A seção Alles klar! do capítulo quatro segue o mesmo padrão do capítulo um: parte do vocabulário é retomado, sempre inserido em frases.

Termine, Termine... é o oitavo e último capítulo do Kursbuch A1.1, e o campo de palavras a ser tratado é sobre horários, momentos do dia e meses do ano. Novamente inicia-se com imagens de pessoas em seus locais de trabalho, além de seus nomes, idades e profissões. Logo abaixo está o vocabulário referente aos momentos do dia, sendo que o primeiro exercício propõe uma conversa com a turma a partir da pergunta Wer arbeitet wann? (Quem trabalha quando?), fornecendo a resposta sobre uma das pessoas como exemplo. O segundo exercício é um áudio junto com imagens de relógios, ensinando aos aprendizes a pergunta e possíveis respostas quanto às horas. Também há uma lista com imagens de relógios analógicos e digitais e tais horários escritos de maneira formal e informal. Esses conteúdos estão presentes em vários outros exercícios ao longo do capítulo.

No capítulo oito, os meses do ano aparecem na imagem de um livro de anotações, no qual o personagem Jochen Krause conta em uma frase curta o que aconteceu em cada mês. Com isso, é dada a pergunta Was war im Januar? (O que aconteceu em janeiro?) e a resposta, para que os alunos sigam exercitando o vocabulário como no exemplo. Os meses também aparecem em lista, com imagens representativas da estação, como der Juli junto da foto de um sorvete, já que na Alemanha é verão nessa época, além das outras formas de dizer o mesmo mês no país austríaco, por exemplo. 
Feita a exposição do ensino de vocabulário do livro, é possível constatar nos três capítulos analisados que há exercícios de interação variados com ações que promovem a linguagem ativa - a fala é bastante incentivada - e que reforçam a aprendizagem do vocabulário novo. Além disso, o vocabulário vai sendo apresentado de forma gradual ao aluno, como no capítulo um em que se usa apenas palavras no singular e no quatro onde aparecem também os plurais.

Na grande maioria dos exercícios, a língua é vista somente "como um código, ou seja, um conjunto de signos que se combinam segundo regras e que é capaz de transmitir uma mensagem, informações de um emissor a um receptor" (TRAVAGLIA, 1996, p. 22). No exercício do capítulo quatro, em que os alunos devem dialogar com o colega usando os adjetivos, há, por exemplo, uma estrutura definida de perguntas e respostas, já previstas no livro através dos exemplos ali postos, o que torna o locutor e o interlocutor em emissor e receptor, não sendo possível haver uma situação real de comunicação para que a mensagem seja transmitida e entendida.

Verificou-se que não há a utilização da linguística de corpus para a seleção do que ensinar ou para como ensinar, visto que quase não há textos nessa versão do livro, e os poucos textos que têm não são usados com a finalidade de abordar os padrões reais de uso da língua. Quanto à concepção de linguagem, nota-se a concepção de linguagem como instrumento de comunicação, como por exemplo o uso exclusivo da norma culta, isso porque, como afirma Saussure em seu Curso de Linguística Geral, a língua é vista como um sistema abstrato e de "natureza homogênea" $(1969,23)$ Esse uso exclusivo também revela que há, parcialmente, o oferecimento de uma visão ampla da língua alemã. Parcialmente porque a visão ampla de língua corresponde apenas à norma culta, não havendo espaço para os inúmeros dialetos presentes na Alemanha, Áustria e Suíça, por exemplo. Porém, é justo dizer que sempre é concedido ao estudante o equivalente das palavras também no alemão austríaco e suíço, bem como os ambientes de vida desses países - como afirmou a editora Cornelsen.

De modo geral, pode-se concluir que os livros da coleção Panorama são inovadores por explorarem um ensino que ultrapassa as fronteiras da Alemanha, envolvendo outros países que também têm o alemão como língua oficial. Vale ressaltar, no entanto, que nesses países está muito presente o uso de dialetos no dia a dia das pessoas, não apenas a norma culta. Sendo assim, tais dialetos podem ser abordados pelo professor como conhecimento complementar ao que trazido pelo livro. Pode-se afirmar, ainda, que é visível que há uma preocupação em oferecer aos alunos exercícios variados e que envolvam as quatro habilidades 
- leitura, escrita, fala e audição -, a fim de colaborar com o ensino e a fixação do vocabulário de uma forma que não seja cansativa ou repetitiva.

\section{Referências:}

FINSTER, A. et al. Panorama: Deutsch als Fremdsprache. Berlin: Cornelsen Schulverlage GmbH, 2015.

MONTEIRO, L. M. T. Aquisição do Léxico em língua estrangeira: da aplicação de práticas cooperativas e seus resultados. Linguagem \& Ensino. Pelotas, v. 11, n. 1, p. 179-199, jan./jun. 2008. Disponível em: http://www.rle.ucpel.tche.br/index.php/

NATION, P. and NEWTON, J. (1997). Teaching vocabulary. In Coady, J. and Huckin, T. (eds.) Second Language Vocabulary Acquisition. Cambridge:Cambridge University Press.

SARMENTO, S. Linguística de corpus: histórico, metodologia, campos de aplicação. Revista Trama - Volume 6 - Número 12 - 2o Semestre de 2010 - p. 87 - 107.

SAUSSURE, F. Curso de lingüística geral. Tradução de CHELINI, A. \& PAES, J. P. \& BLIKSTEIN, I. São Paulo: Cultrix, 1969.

TRAVAGLIA, L. C. Concepções de linguagem. In: Gramática e interação: uma proposta para o ensino de gramática no $1^{\circ}$ e $2^{\circ}$ graus. São Paulo: Cortez, 1996.

Editora Cornelsen - Panorama: https://www.cornelsen.de/panorama/1.c.3476169.de Acesso em: 22/02/2018. 